\title{
"Oortuiging" en prediking: woordspel op 'n "hartspel"
}

C J S Lombaard

(Universiteit van Pretoria)

\section{ABSTRACT}

\section{Persuasion/Conviction and Preaching: Word Play on a Heart Game}

This article employs a wordplay on "oortuiging" - persuasion and integrity - to analyse certain aspects of homiletics. Examples of the use of research into persuasive communication and the benefits of these perspectives for effective preaching are given. Of greater importance, though, is the integrity of the preacher, which has three dimensions: that ministers should themselves be convinced of the theology of the text from which they preach, that the concrete contexts of the hearers of the message should be addressed competently, and that exegetical methodology and homiletical pronouncements should correspond.

\section{1 'N HARTSPEL...?}

Prediking is in twee opsigte " $\mathrm{n}$ "hartspel". In die eerste opsig is prediking iets wat vir ons as belangstellendes ${ }^{1}$ in hierdie omvormende kunsvorm ná aan die hart lê. Om die lewende Woord van die lewende God in 'n preek ná te praat ${ }^{2}$, bly aangrypend-onbegryplik. Ons kan prediking ontleed in verskillende dimensies, maar dan bly daar altyd iets onontleedbaars oor - ' $n$ misterie. Spiritualiteit en prediking bly daarom eng verbonde aan mekaar, en vind mede neerslag in die wese (die eksistensie) van die prediker. Prediking raak óns bestaan, ons menswees, ons roeping aan die hart....

Maar prediking is, tweedens, ook 'n "hartspel" omdat dit aan die kern lê van gelowige-wees en gemeente-wees. Die praedicatio verbi Dei, spesifiek in die Reformasie-teologie, is "n "hartsaak": nóg die individuele gelowige, nóg die gemeenskap van die gelowiges (die gemeente) is denkbaar in tradisionele Gereformeerde denke sonder die prediking van die Skrif as polsslag (vgl bv Rossouw 1963:140ff; 205-213).

${ }^{1}$ Hierdie artikel is ' $n$ verwerkte weergawe van ' $n$ referaat gelewer op Saterdag 21 Augustus 1999 tydens ' $n$ seminaar oor prediking gereël deur die uitgewer Lewende Woorde, verbonde aan die Departement Griekse en Latynse Studies, Randse Afrikaanse Universiteit, waar die seminaar ook gehou is.

2 "The critical paraphrase... is the crown of any interpretation"-Von Rad 1965/66:13. 
As ons die spel $^{3}$ van prediking speel, impliseer die dinamika van hierdie spel dus, breedweg, twee "speelrigtings" as die prediker as vertrekpunt geneem word:

* na buite - húlle wat die preek aanhoor (die gelowige/die gemeente); en

* na binne - óns as predikers, belangstellendes, entoesiaste.

Ek gaan hierdie tweedeling gebruik om 'n paar opmerkings te maak rondom die term "oortuiging". Eers wil ek oortuiging betrek op die hoorder (Dingemans 1991 se terminologie; sien veral bladsye 51-65 van sy werk; kyk plaaslik onder andere Pieterse 1988:79-128); daarna wil ek oortuiging betrek op die prediker.

\section{OORTUIGING EN DIE HOORDER VAN DIE PREEK}

Oor die teologiese aspek wil ek hier nie uitbrei nie ${ }^{4}:$ ek neem dit gewoon as gegewe dat ' $n$ mens, by wyse van spreke, ' $n$ instrument is in enige proses waar die evangelie oorgedra word. Die werklike oortuigingswerk bly die terrein van die Heilige Gees.

Tog, as instrument, kan ' $n$ mens sekere kommunikasieveranderlikes aanwend (vgl Burger 1991:27-30): afhanklike diensbaarheid beteken nie inisiatiefloosheid nie. Drie van dié veranderlikes wat binne ' $n$ (ver)Westerse kultuur toepaslik is ${ }^{5}$, word aangeraak ${ }^{6}$. In navolging van die bekende (maar oorvereenvoudigende ${ }^{7}$ ) kommunikasiemodel "Sender-Boodskap-Ontvanger", word telkens een aspek gekies uit

\footnotetext{
${ }^{3}$ Hierdie tipe metafoor word deesdae al hoe meer in Afrikaanse teologiese geledere gevind: eksegese is ook al as spel beskryf (Le Roux 1996:46-56), dogmatiekhomiletiek as dansmaats (Vos 1994:52-64), die erediens as fees en die liturgie as dans (Müller 1990 se hele werk, en p 107 onderskeidelik) - met gemengde reaksie (o a Prinsloo 1996:21-33; Heyns 1994:158-159). Ook die Nederlande Ou-Testamentikus $\mathrm{E}$ Noort het tydens ' $\mathrm{n}$ onlangse kongres in Pretoria die volgende opgemerk: "eksegese is kuns... koorddans sonder vangnet...".

${ }^{4}$ Raadpleeg gerus die tradisionele dogmatiek-werke insake die teologiese aspekte van die prediking. Ook, resent, plaaslik en opsommenderwys: Beukes 1993:34-44. Oor die "Gepredikte Woord" of "Verkondigde Woord" het J A Heyns (1977:8-20; 1978:146-147; 1988:82 - vergelyk Jonker 1994:21-22) plaaslik die "Woord-spel" van Karl Barth (1955:89-127) uitgebrei.

${ }^{5}$ Die kultuurbepaaldheid van retoriese tegnieke moet nooit oor die hoof gesien word nie. Retoriek is nie bowe-kultuurlik nie. Hierdie besef lei tot redelik ernstige vrae rondom die retoriese kritiek in die analise van die Bybel.

${ }^{6}$ Hierdie veranderlikes is gekies bloot op grond van persoonlike voorkeur, en daar is vele meer sulke veranderlikes- sien byvoorbeeld Mulholland 1994; Bettinghaus \& Cody 1994; Ross \& Ross 1981.

${ }^{7}$ Sien byvoorbeeld Severin \& Tankard 1992:38-53; meer algemeen: Littlejohn 1996; plaaslik en toegepas op die prediking: Webb 1986:35-45.
} 
navorsing oor, onderskeidelik, Sender-, Boodskap- en Ontvangerveranderlikes ${ }^{8}$. Telkens word eers die kommunikatiewe agtergrond gegee (hierin word redelik sterk gesteun op Lombaard 1990:116-124, 141), waarna die toepassing daarvan binne die konteks van die prediking uitgelig sal word.

In die aanduiding van hierdie veranderlikes, is dit nie moontlik om al die verbandhoudende sake aan te dui nie ${ }^{9}$. Hierdie inhoude is dus gedekontekstualiseer, en sal moeilik effektief aangewend kan word sonder dat die verbandhoudende sake ook eers in berekening gebring word. Tog bied dit eerste insigte in die moontlike waarde wat deur hierdie tipe navorsing gebied kan word.

\section{1 'n Sender-veranderlike: Die "sleeper"-effek}

Die aanvaarding van ' $n$ boodskap, veral ' $n$ oorredingsboodskap, deur ' $n$ ontvanger is veral aanvanklik sterk gekoppel aan die waargenome geloofwaardigheid van die sender. Dié saak is goed bevestig in die navorsing (vgl Severin \& Tankard 1992:153-157). Die "sleeper"-effek behels egter dat, met verloop van tyd, die identiteit en rol van die sender van ' $n$ spesifieke boodskap in die geheue van die ontvanger geskei word van die inhoud en effek van die boodskap. Dit beteken dat ' $n$ hoogsgeloofwaardige persoon se boodskap aanvanklik ' $n$ sterk oorredende effek kan hê, maar dat hierdie boodskapinvloed met verloop van tyd afneem. In die geval van ' $n$ sender met 'n lae waargenome geloofwaardigheid, is die teenoorgestelde egter waar. Soos wat sender en boodskapinhoud mettertyd in die gedagtes van die ontvanger geskei word, sal die boodskap aan invloed toeneem (vgl Drop et al 1972:31-33).

Die implikasie is dus dat oorredingsinvloed en sender mettertyd al hoe meer onafhanlik van mekaar in die gedagtewêreld van die ontvanger funksioneer. Die "sender se invloed, hetsy positief of negatief, (neem dus af), sodat die inligting toenemend op eie meriete beoordeel word" (Lombaard 1990:116).

${ }^{8}$ Die gebruik van kommunikasieteorie ter verryking van die homiletiek en die praktiese teologie in die algemeen, is geen nuwigheid in Afrikaanse teologienavorsing nie. Sien veral die werke van H J C Pieterse en C J A Vos, wat saamgevat word in Vos \& Pieterse 1997:15-28. Sien ook Heyns \& Pieterse 1990; Nel 1994: o.a. pp 21f, 83f, 291; Webb 1986:31-61; Cronjé \& Van Wyk 1982. Met my keuse hier van dié drie elemente in die kommunikasieproses - te wete, Sender, Boodskap en Ontvanger - probeer ek die te enge onderskeid in die praktiese teologie tussen die klem op óf die pastor óf die gemeente (sien L M Heyns in Heyns \& Pieterse 1990:18-19) ondervang. Sowel die kommunikasiegebeure in die erediens as geheel as enige van die elemente daarvan is ' $n$ legitieme studieveld.

${ }^{9}$ Sien byvoorbeeld Bettinghaus \& Cody 1994 en Mulholland 1994 vir 'n goeie oorsig oor navorsing in die oorredingskunde. Vir verdere bronne sien onder andere http://carmen.artsci.washington.edu/propaganda/contents.htm en http://directory. netscape.com/Science/Social_Sienes/Psychology/Persuasion_and_Social_Influence/ 
Die invloed van hierdie "sleeper"-effek, is bevind, kan deur middel van sekere tegnieke aangewend word ter wille van groter oorredingseffektiwitiet. Één daarvan is waarskuwing teen teenbeïnvloeding. Indien ' $n$ ontvanger reeds ' $n$ boodskap aanvaar, is dit moontlik om hierdie aanvaarding stewiger te anker deur die ontvanger daarop te wys dat daar ander kompeterende "interpretasies" is. Hiedie teenargumente kan gelys en bespreek word. Selfs al word teenargumente egter net in verswakte vorm bespreek, of dit word bloot genoem dát daar teenargumente bestaan, kan dit die opinie wat die ontvanger tans huldig, help "innokuleer". Aansluitend by die "sleeper"-effek, vergroot die invloed van hierdie waarkuwing/"innokulasie" oor tyd heen, sodat weerstand teen latere beïnvloeding mettertyd vergroot (Drop et al 1972:3133; Williams 1984:92).

Die implikasies hiervan vir die preaiking, is kortweg, goeie nuus vir "swak" sprekers en slegte nuus vir "goeie" sprekers:

* Vir predikers met ' $n$ lae waargenome geloofwaardigheid as gevolg van, byvoorbeeld, ongemaklike openbare optrede, beteken dit dat alles nie verlore is nie. Hulle boodskappe mag wel op die kort termyn minder effektief blyk te wees omdat hulle "swak sprekers" is, maar mettertyd word die boodskapinhoud en die sender van mekaar geskei in die gedagtewêreld van die ontvangers. Die boodskap sal dan aan invloed toeneem. In kerklike taal: die evangelie word dus steeds goed bedien, oor tyd heen, ten spyte van dorings in die vlees ( 2 Kor 12:7, met apologie) van die prediker.

* Met "goeie" sprekers is dit anders gesteld. Predikers met ' $n$ hoë waargenome geloofwaardigheid, wat dikwels deur kerkgangers verbind word daaraan dat die predikante "goeie sprekers" is, word maklik invloed-ryk deur hulle prediking. Mettertyd egter, soos wat boodskapinhoud en sender van mekaar geskei word in die gedagtewêreld van die ontvangers, verloor die boodskap aan oortuigingskrag. Waargenome sendergeloofwaardigheid kan dus nie onbepaald die waargenome meriete van 'n boodskap "dra" nie. Dit is dus, oor die lang termyn, slegte nuus veral vir predikante wat deur middel van " $n$ "persoonlikheidskultus" die evangelie bedien.

Die insig dat ' $n$ goeie spreker en ' $n$ goeie prediker nie noodwendig dieselfde ding is nie, vind dus hier ook uitdrukking.

In verband met die waarde van waarskuwings teen teenbeïnvloeding (die "innokulasie"-effek) en die "sleeper"-effek daarmee verbonde, net enkele kernopmerkings. Hierdie verskynsel verklaar onder andere die effektiwiteit van jeugbediening ( $v g l ~ N e l ~ 1982: 72)$ op ' $n$ vroeë ouderdom, maar ook die weerstand teen nuwere Bybeluitleg in die kerk. 
Vroeëre "waarskuwings" teen, onderskeidelik, nie-Christelike lewenswyses en ' $n$ ander Bybelbegrip, speel bepaald ' $n$ rol in die permanensie van hierdie gevestigde houdings ${ }^{10}$.

Voorbeelde van verdere moontlike toepassings hiervan kan vermenigvuldig word.

\section{2 'n Boodskap-veranderlike: Kongruensie-skepping}

Gemeenskaplike gronde tussen sender en ontvanger is die basis van waar af (nie-geforseerde) oortuiging moontlik word. Hierdie gedeelde belange moet vroeg in die boodskap reeds gestel word; dit is " $n$ "aanvangstaak" (Lombaard 1990:116). Soos wat enige openbare speker weet, moet die gehoor se belangstelling vroeg reeds getrek word. Die aanduiding van gemeenskaplikhede wen ook vertroue, wat die sender se geloofwaardigheid - een van dié belangrikste oorreedingsveranderlikes - verhoog ${ }^{11}$.

Taal en spreekstyl in die boodskap is " $n$ goeie manier om identifisering met die sender te verhoog (Rall 1980:25). Daarmee saam moet die argumente in die boodskap direk in verband gebring word met die ontvanger se "huidige probleme, houdings, verwagtinge, ideale, behoeftes en waardes" (Lombaard 1990:117). Hierdie sake moet aangeraak word in die "probleem" wat vroeg in die boodskap gestel word, en, belangrik, ook in die verlangde "oplossing" wat aangebied word. Maniere waarop 'n effektiewe "oplossing" (dit is die oorredingsintensie) aangebied kan word, sluit in (ter opsomming van Fleming \& Levie 1978:214-216 en Lerbinger 1977:10):

* bied "beginselkennis": dit wil sê inligting wat die onbekende verstaanbaar, aanvaarbaar, en dan positief voorstel;

* dui die "gebruikswaarde" aan: die voorstel wat aan die hand gedoen word, moet ooglopend effektief blyk te wees in die oplossing van ' $n$ sekere probleem of in die weerspieëling van ' $n$ belangrik-geagte waarde;

* die "aanpasbaarheid" van die voorstel: "n rigiede voorstel sal moeiliker aanvaar word as een wat aangepas kan word binne onderskeie kontekste, soos wat dit individue/groepe se kontekstuele eise en voorkeure pas;

* die "ego-funksie": voorstelle wat die moontlikheid bied om uitdrukking te gee aan die selfbeeld van die ontvanger, staan ' $n$

${ }^{10}$ Houdings kan omskryf word as "the internal mental and emotional states that affect how we react to outside persuasion... our feelings, beliefs, or ideas that affect how we may eventually behave"- Williams 1984:87.

11 Vergelyk die titel van die hoofstuk "The magic of rapport" in die populêre werk van Zucker 1994:67-75. 
goeie kans op sukses ${ }^{12}$. Die ideale selfkonsep word ook hierin betrek: die strewes van die ontvangers word ook ingesluit.

* interessantheid: prikkeling van ontvangers se belangstelling bly ook hier belangrik;

* geloofwaardigheid: stellings wat gemaak word, moet as geldig waargeneem word.

Natuurlik moet die kongruensie wat die boodskap skep tussen sender en ontvanger genoeg ruimte laat vir verskil: sonder verskil is oortuiging onnodig (Lombaard 1990:118). 'n Te groot oorvleueling tussen sender en ontvanger se opinies impliseer dikwels vir ' $n$ ontvanger dat verandering onnodig is (die "assimilasie-effek"); ' $n$ te ekstreme verskil tussen sender en ontvanger veroorsaak weer dat die boodskap as meer ekstreem waargeneem word as wat dit werklik is (die "kontras-effek" - Lerbinger 1972:74; cf Sandell 1977:77), wat daartoe lei dat die boodskap óf geïgnoreer, óf verwerp, óf tot aanvaarbaarheid verdraai word (Rall 1980:2; Sampson 1964:277). Die "aanvaardingsveld" - die sielkundig-aanvaarbare "grense" vir " $n$ boodskap om potensieel aanvaar te word (Triandis 1971:187) - moet dus versigtig binne die boodskap daargestel word. Indien tyd dit toelaat, kan tegnieke soos die "voet-in-die-deur" 13 en die "deur-in-die-gesig"" as oorredingstrategieë aangewend word (Lerbinger 1972:74).

Om hierdie saak te betrek op die prediking, word ' $n$ denkbeelde situasie geskets: ' $n$ predikant wil die gemeente betrokke kry by ' $n$ voedselskema vir armes in die middestad. Die gedeelde belange moet dus eers in die preek gestel word - sake soos liefde tot God en liefde tot die naaste, met laasgenoemde wat ook praktiese hulp aan armes beteken. As die gedeelde basis van empatie en roeping tot optrede ${ }^{15}$ wat predikant en gemeentelede deel, gestel is, kan dié saak nou ook verbind word aan verdere gedeelde behoeftes (bv in verband met probleme: voorkom diefstal deur voedsel te voorsien; in verband met ideale: streef na ' $n$ gemeenskap waar almal genoeg het). Deur verder "beginselkennis" oor te dra (oor hoe die projek prakties geloods kan word), en deur die "aanpasbaarheid" van die projek (bv by individue se besige programme) aan

12 Interessant genoeg, lyk dit of "n aggresiewe, outoritêre oorredingsappèl die mees effektiewe oortuigingsmetode is indien met outoritêre persoonlikhede gewerk word.

${ }^{13}$ Die "voet-in-die-deur"-tegniek stel eers 'n meer gematigde standpunt; indien dit aanvaar word, word hierop voortgebou na ' $n$ meer progressiewe standpunt.

${ }^{14}$ Die "deur-in-die-gesig"-tegniek stel eers 'n te ekstreme standpunt, wat beslis verwerping sal ontlok; later word dan ' $n$ meer gematigde standpunt aangebied, wat minder ekstreem lyk as wat dit sou geblyk het as dit van die begin af gestel is. Daarom word dit vervolgens makliker aanvaar.

${ }^{15}$ Die verhouding tussen houding en gedrag is egter nie noodwendig of eenvoudig nie (Vgl Williams 1984:93-96) vir 'n opsomming hiervan. 
te toon, word die kanse op effektiewe oortuiging vergroot. Indien gemeentelede vermoedelik traag sal wees om betrokke te raak, kan die voet-in-die-deur tegniek moontlik gebruik word - deurdat aanvanklik 'n baie beperkte betrokkenheid by die projek as ideaal gestel word.

Kongruensie tussen prediker en gemeente word dus in die boodskap uitgespel. Dít word dan gebruik as basis in die oortuigingsproses.

\section{3 'n Ontvanger-veranderlike: Selfagting}

Selfagting is die waarde wat persone aan hulleself heg (vgl Ross \& Ross 1981:31). Hoe laer persone se selfagting is, hoe meer oorreedbaar blyk hulle te wees, te meer deur persone met ' $\mathrm{n}$ hoë waargenome selfagting. Lae selfagting impliseer naamlik dat eie opinies as van minder waarde as dié van ander persone geag word.

Selfagting is een van die belangrikste ontvangerveranderlikes insake die effektiwiteit van ' $n$ oortuigingspoging. Dit hang egter saam met sake soos intelligensie, opvoedingspeil, en dies meer, omdat hierdie sake weer bepaal in hoe ' $n$ mate rasionele en emosionele boodskapelemente (in so ' $n$ mate as wat hulle onderskeibaar is - Rall 1980:20) aansluiting vind by die oorredingsvatbaarheid van die ontvangers (Lerbinger 1972:71).

In die geheel gesien beteken hierdie vertrekpunte dat rasionele argumente aan te beveel is vir ontvangers met ' $\mathrm{n}$ hoë opvoedingspeil, as die gevolge van die boodskap helder tuisgebring moet word by die ontvangers, of as die onderwerp tegniese onderskeidings benodig (Rall 1980:20). Dít is tipies die soort boodskappe wat aan persone met ' $n$ hoë opvoedingspeil gebring sal word. Omdat dié groep mense weens ' $n$ suksessirkel in hulle lewens (vgl Jones 1977) geneig sal wees tot hoë selfagting, sal ' $n$ appèl op hulle denke, eerder as hulle emosies, die beste oorredingsresultate verkry.

' $n$ Emosionele aanpak is meer gepas waar die ontvangers die sender reeds vertrou (Johannesen 1967:38), waar ideale, begeertes of optrede sonder vergoeding van die ontvangers verlang word, en waar die ontvangers ' $n$ lae intelligensie/opvoedingspeil het (Rall 1980:20; Andersen 1971:158). Met laasgenoemde waarskynlik die belangrikste van hierdie veranderlikes (wat dus ' $n$ groot impak sal hê op die ander veranderlikes), is die implikasie dat rasionele argumentvoering - ten spyte van die Westerse vertroue op die rede - waarskynlik onsuksesvol sal wees om ongesofistikeede mense se houdings/gedrag te verander ${ }^{16}$.

Om hierdie oorredingsaspek op die prediking toe te pas: sommige van die geloofsherlewings in die negentiende eeuse kerkgeskiedenis het

16 Hierdie insig open belangrike perspektiewe vir byvoorbeeld HIV/VIGSvoorkomingsprojekte in veral landelike gebiede. 
gepaard gegaan met groot klem op die wederkoms-en-oordeels-teologie (vgl Bosch 1991:281-283, 313-327). Vrees was ' $n$ belangrike motief in dié tipe prediking, en vrees is juis een van dié mees kragtige emosionele appèlle - indien gematigd aangewend (vgl Severin \& Tankard 1992:167161; Lombaard 1990:121-123). Die herlewings was suksesvol in dié sin dat groot groepe mense hulle tot die Christendom, of tot groter "Christelikheid", bekeer het.

Tans reageer teoloë egter dikwels negatief op die moontlikheid dat dié tipe prediking nog in bekeringsveldtogte aangewend word. Kommunikasiekundig beskou, is dít aanduiding van twee sake:

* dit is eintlik te verwagte dat teoloë, weens ' $n$ hoër opvoedingspeil en daarmee gepaardgaande hoë selfagting, negatief op hierdie emosionele vreesboodskappe sal reageer, ongeag of dié boodskappe direk op hulle gerig is of nie;

* aan die ander kant verwoord teoloë wat dié sendingmetode kritiseer waarskynlik akkuraat ' $n$ kultuur-historiese tendens, naamlik dat mense oor die algemeen (minstens in Westerse en verwesterse lande) tans ' $n$ baie hoër opvoedingspeil het as wat die geval was tydens hierdie groot herlewingsbewegings.

Daarom is dit waarskynlik geldig om op te merk dat sowel die opvoeding/selfagting van die teoloë as dié van die samelewing tans, kommunikasiekundig gesproke, die groeiende afkeur in emosionele, vreesopjaende prediking verklaar.

\subsection{Samevatting}

Uit bostaande blyk dat die aanwending van kommunikasienavorsing, spesifiek oorredingsnavorsing, interessante en bruikbare perspektiewe vir die prediking kan bied. Wat hier aangebied is, is egter bloot eerste treë. Voordat met enige gesaghebbendheid oor dié sake gepraat kan word, is veel meer interdissiplinêre navorsing ${ }^{17}$ nodig.

Laat ek daarom vir eers hierby volstaan, en oorbeweeg na die tweede deel van my woordspel rondom oortuiging en prediking.

\section{OORTUIGING EN DIE VERBI DIVINI MINISTER}

Een van my leermeesters, Professor Wil Vosloo, is iemand wat verseg om twee sake van mekaar te skei: die harde akademiese studie van ' $n$

${ }^{17}$ Insluitend teologie, sielkunde, sosiologie, kommunikasiekunde, filosofie, etiek, kultuurstudies, en dies meer. 
Bybel-teks, en die sinvolle pastorale - dit is, kerklike - toepassing van hierdie arbeid. Een van sy "spreuke" wil ek hier aanhaal ${ }^{18}$ :

'n goeie prediker het drie kenmerke:

hy/sy sal die gemeente wat voor hom/haar sit, goed ken;

hy/sy sal die betrokke Bybelteks goed ken; en

hy/sy sal opreg glo, dít wat hy/sy verkondig.

Dit is oor die laaste frase wat ek eerste iets meer wil sê. 'n "Goeie prediker"19 is een wat van harte glo dít wat in sy/haar preek verwoord ${ }^{20}$ word. Anders gestel: wat ' $n$ goeie prediker bring, is ' $n$ boodskap met integriteit - die boodkapper se wese word mede in die kerugma (verkondiging/boodskap) opgeneem. Ek gló wat ek preek. Níé omdat ek my troeteltemas bepreek nie, maar omdat ek myself geheel oortuig vind van die boodskap van die Bybelteks wat my - en dan my hoorders - intrek. Dit gaan dus nie net daarom dat ek die Bybelteks verstaan nie, maar óók dat ek myself - en dan my hoorders húlleself - in die Bybelteks verstaan vind (vgl Rossouw 1963:229-245). Die Bybel lees mý, respektiewelik: óns.

Hiedie "oortuiging" van die prediker is dus om oortuig te wees van die integriteit (teologies-eksistensieel en prakties) van sy/haar aangespreek wees en nápraat van die Bybel.

Hiérdie oortuiging wat met prediking gepaard gaan, het sekere voorvereistes, wat ons by die eerste twee dele van die Vosloo-spreuk hierbo terugbring.

' $n$ Prediker wat sy/haar gemeente nie ken nie, kan moeilik meer as tydlose waarhede kwytraak. Hoewel dít deel van die (ver)Westerse kerkstroming se tradisie is (vgl Nürnberger 1999:21-23), is dit nét te Grieks-filosofies, nét te Westers om altyd reg te laat geskied aan die kontekstuele gesitueerdheid van die evangelie ${ }^{21}$. 'n Preek moet neerslag vind grondvat in die spesifieke konteks van die hoorders ${ }^{22}$. Dit is des te moeiliker in (ver)Westerse kerke en denke, wat beginels bo praktyk stel.

${ }^{18}$ Let egter daarop dat hierdie 'n "orale uitspraak" is. Sover ek weet, het Vosloo nooit hierdie insigte op papier neergepen nie.

${ }^{19}$ Vergelyk die opmerking hierbo oor goeie sprekers en goeie predikers...

${ }^{20}$ Die woord "verwoord" is doelbewus gekies: dit verwys na voetnota 2 van hierdie artikel. Prediking in die reformatoriese tradisie is nie die kwytraak van eie wyshede nie, maar bly die nápraat van die Skrif. Vergelyk Von Rad (1965/66:11-18).

${ }^{21}$ Sien Nolan (1988:15) in verband met "universalising truths".

22 Die erns van dié konkreet-historiese dimensie spreek onder andere ook daaruit dat vele studies wat erns maak met die sosio-historiese agtergrond van die Bybelse tekste, tot soortgelyke gevolgtrekkings as dié van, byvoorbeeld, Strijdom \& Van Aarde (1990:185) kom: "dat teologie in ' $n$ konkrete sosio-historiese konteks funksioneer, en nie in abstracto nie". 
Maar hierdie "spesifieke konteks" is nie enkelvoudig nie. Gemeentelike konteks sluit in: belangrike sake in die lewe van individuele gemeentelede; singewende momente in die lewe van die gemeente as geheel; die nouer (plaaslike) en breër (internasionale) sosio-politiese en kulturele konteks ${ }^{23}$; die ekologiese konteks, die ekonomiese konteks (Marx is dood...?), en dies meer ${ }^{24}$. Die eerste twee van hierdie aspekte kan moeilik aangeraak word deur ' $n$ gas-prediker in 'n gemeente; al die ander moontlikhede bly egter nog beskikbaar.

Die Afrikaanse kerke se teologiese opleiding gee egter min aandag aan hierdie "buite-persoonlike" realiteite (vgl Lombaard 1999:22-24). Dit maak dit alreeds moeilik vir persone wat deur so ' $n$ leerskool gegaan het, om oor hierdie sake te preek. Daarmee saam: baie mense wat besluit om predikant te word, neem dié besluit om hulle "iets wil beteken vir mense". Beide hierdie tendense word gekleur deur kerklike en persoonlike geskiedenisse met ' $n$ sekere soort piëteit (naamlik piëtisme), gepaardgaande met ' $n$ redelik eng (en on-Calvinistiese!) siening van "roeping" (meer spesifiek: roepingsterreine; vgl McKim 1992:339-341). Al hierdie aspekte maak dit makliker vir predikers om "ewige waarhede" (vir die brein) eerder as kontekstueel-relevante boodskappe (vir die hele mens) te lewer ${ }^{25}$.

Sodanige eensydige klemtone in die prediking verarm nie alleen die hele onderneming van prediking nie, maar verskraal ook die areas wat aange(s)preek word. Al hierdie kontekste (sosio-polities, kultureel; ekologies, ekonomies) moet met oortuiging aangeraak word in die prediking, te meer omdat die Gereformeerde Christendom by uitstek nog altyd God se heerskappy oor al hierdie sake bely het. "It is never possible to express the Word in timeless abstractions, but each witness must use his

${ }^{23}$ Christelike, dit is Bybelse, prediking as kultuurkritiek bly ' $\mathrm{n}$ grootliks onontginde dimensie van prediking, klaarblyklik oor alle kulture heen. Dit is óf as gevolg daarvan dat ons dikwels onbewus is van ons eie kulturele aannames (wat ons dan gewoon in die Bybel "in-lees" of selektief "rááklees"), óf weens ' $n$ on(der) ontwikkelde vermoë om kultuur (gebruike, aannames, "waarhede", tradisies, mensbeelde, verhoudinge, tendense, "mites") krities te "lees", óf omdat dit psigologies so ongemaklik is om ' $n$ mens se eie kultuur te bevraagteken.

${ }^{24}$ Harrington 1980:190 (vgl Strijdom \& Van Aarde 1990:185) merk hieroor op: "The great interpreters from Origin to Bultmann have studied biblical texts with an eye toward individual experience and have relied on various kinds of philosophical anthropology. Yet critics of this personalist approach always point to the communal and social character of NT writings. They correctly demand a hermeneutic more appropriate to the material being studied. Perhaps the critical use of sociological concepts will help toward developing a socially-oriented method of interpretation".

${ }^{25}$ Dit impliseer nie dat een van dié twee nou on-Christelik is nie. Beide is historiese uitdrukkings van verskillende Christelikhede. Nürnberger (1999:22-23) argumenteer in hierdie rigting deur sy gebruik van die inklusiewe frases "Christian fold" en "versions of Christianity". 
own contemporary language" (Schweizer 1970:23; vgl Strijdom \& Van Aarde 1990:185).

Om met oortuiging oor hierdie sake te kan preek, verg egter ' $n$ goed ingeligte prediker. Dit is daarom ' $n$ belowende ontwikkeling wat tans in teologiese opleiding plaasvind, dat studente by sommige instellings ook ' $n$ hoofvak uit ' $n$ ander, tradisioneel nie-teologiese terrein kan neem as deel van ' $n$ teologiegraad. Dit sal aan predikante die instrumente voorsien om met kompetensie oor verskillende kontekste te kan preek. Die kerke staan dus 'n beter kans om naas "ewige waarhede", ook tydgebonde, aktueel-relevante preek-"uitsette" te voorskyn te sien kom.

Oor die voorlaaste deel van die Vosloo-spreuk (die predikant sal die betrokke Bybelteks goed ken), wil ek nie veel sê nie; die meeste wat ' $n$ mens hieroor kan sê is ooglopend. Die belangrikste vir ' $n$ predikant om met geloofwaardigheid en oortuiging te kan preek, bly vir my dat eksegetiese metode, preekinhoud en lewenstoepassing ${ }^{26}$ by mekaar sal aansluit.

Om dit met ' $n$ voorbeeld konkreet te stel: van tyd tot tyd word gevind dat die Pretoria-skool ${ }^{27}$ van struktuur-analitiese eksegese die vertekpunt vorm om in ' $n$ preek uitsprake oor die historiese Jesus te maak. Diegene wat bekend is met die Suid-Afrikaanse eksegese-debat ${ }^{28}$, sal bewus wees daarvan dat vir die grootste deel ${ }^{29}$, plaaslike struktuuranalitici historiese navorsing wantrou en hulle bevindinge beperk tot die teks, eerder as om hulle te waag aan die geskiedenis van waaruit die teks voortkom. Die filosofiese aannames en die eksegetiese praktyk wat met hierdie teksimmanente metode saamgaan, maak dit beswaarlik moontlik om oor geskiedenis iets te sê. Die teks staan op die voorgrond. Daarom is dit myns insiens nie moontlik om byvoorbeeld oor die historiese Jesus te preek, as 'n a-historiese metode van Bybeluitleg gevolg is nie (vgl Lombaard 1996:106-113). Die integriteit van die ineengestrengelde proses van eksegese-preek-toepassing word daardeur gekompromiteer.

Om ' $n$ preek te lewer wat oortuig - ten spyte daarvan dat ' $n$ mens van die eksegetiese resultate en hoe dit in die preek opgeneem is, kan verskil - is dit dus van die uiterste belang dat leesmetode en verkondigingsinhoud by mekaar aansluiting vind.

\footnotetext{
${ }^{26}$ Die skeiding van dié drie aspekte bly kunsmatig.

27 Dié benaming is na my beste wete die eerste keer in Lombaard (1997:204) gebruik.

${ }^{28}$ Sien Le Roux (1993) vir 'n oorsig oor die debat binne die (Suid-)Afrikaanse Ou Testamentiese wetenskap tot 1987 . Werke oor die debat binne die plaaslike Nuwe Testamentiese wetenskap, en ' $n$ nuwe verwerking van die 1993-werk in verband met die plaaslike Ou Tesamentiese wetenskap, word tans deur Le Roux voorberei.

29 J A Loader (1998:496-497), byvoorbeeld, is ' $n$ uitsondering.
} 
Die prediker beskik oor metodes om die oortuigingskrag van sy/haar boodskaplewering te bestudeer. Enkele, voorlopige voorbeelde daarvan is hierbo gegee. Van groter belang is egter die integriteit van die prediker self. Integriteit oortuig.

Dit is belangrik vir ' $n$ prediker wat aktueel wil preek om die individu, kerk en samelewing in al hulle fasette op geldige wyses te kan "lees"30. Dít maak oortuigende toepassing van die Bybelteks moontlik. Dit is ewe belangrik om die Bybelteks goed te kan verstaan, op so ' $n$ wyse dat Bybeluitleg, -prediking en -toepassing ' $n$ oortuigende geheel vorm. Van grootste belang is egter dat die prediker homself / haarself ook van die teologie van die betrokke Bybelteks oortuig, verstaan vind. As die prediker vanuit ' $n$ geráákte geloof preek, sal gemeentes veel vergewe, omdat hulle kan meeleef (op verskillende maniere) in die spiritualiteit-met-integriteit waardeur hulle hulself opgeneem vind.

\section{Literatuurverwysings}

Andersen, K E 1971. Persuasion: theory and practice. New York: Allyn and Beacon.

Barth, K 1955. Die kirchliche Dogmatik. 1. Halbband, 7. Auflage. Zürich: Evangelischer Verlag.

Bettinghaus, E P \& Cody, M J 1994. Persuasive communication. $5^{\text {th }}$ edition. Fort Worth: Harcourt Brace College Publishers.

Beukes, M J du P 1993. Erediens I. Pretoria: Kital.

Bosch, D J 1991. Transforming mission. Paradigm shifts in theology of mission. Maryknoll: Orbis Books.

Burger, C 1991. Die dinamika van 'n Christelike geloofsgemeenskap. Nuut gedink oor gemeentes. Kaapstad: Lux Verbi.

Cronjé, J M \& Van Wyk, J A 1982. Van mens tot mens. Kerklike kommunikasie in teorie en praktyk. Pretoria: NG Kerkboekhandel Transvaal.

Dingemans, G D J 1991. Als hoorder onder de hoorders: hermeneutische homiletiek. Kampen: Kok.

Drop, W, Kuitenbrouwer, J, Schellens, P, Verhoefen, G, Voet, A, Vree, A, Weintjies, A, \& Zinkstok, I 1972. Over overtuigen: een orientatie in de persuasive communicatie. Groningen: Wolters-Noordhof.

Fleming, M \& Levie, W H 1978. Instructional message design: principles from the behavioral sciences. Englewood Cliffs: Educational Technology Publications.

Harrington, D 1980. Sociological concepts and the early church: a decade of research. Theological Studies 41, 181-190.

Heyns, J A 1977. Die kerk. Pretoria: NG Kerkboekhandel.

-, 1978. Dogmatiek. Pretoria: NG Kerkboekhandel.

${ }^{30}$ Vyf benaderings hiertoe word in Lombaard 1999 aangetref, naamlik deur die predikant en rolprent-resensent Danie du Toit, die teoloog en skrywer Christo Lombaard, die predikant en skilder Marius Lourens, die predikant en sanger Francois Mulder, en die teoloog en digter Cas Vos. 
-, 1988. Inleiding tot die dogmatiek aan die hand van die Nederlandse Geloofsbelydenis. Pretoria: NG Kerkboekhandel.

-, 1994. 'n Weerwoord. Skrif en Kerk 15/1, 156-176.

Heyns, L M \& Pieterse, H J C 1990. Eerste treë in die praktiese teologie. Pretoria: Gnosis.

Johannesen, R L 1967. Ethics and persuasion. New York: Random House.

Jones, R A 1977. Self-fulfilling prophecies. Social, psychological and physiological effects of expectancies. New York: John Wiley and Sons.

Jonker, W D 1994. In gesprek met Johan Heyns. Skrif en Kerk 15/1, 13-26.

Lerbinger, O 1972. Designs for persuasive communication. Englewood Cliffs: Prentice-Hall.

Le Roux, J H 1993. A story of two ways. Thirty years of Old Testament scholarship in South Africa. Pretoria: Verba Vitae (Old Testament Essays Supplement Number 2).

-, 1996. Eksegese is ' $n$ spel. Acta Theologica 16/1, 46-56.

Littlejohn, S W 1996. Theories of human communication. $5^{\text {th }}$ edition. Belmont: Wadsworth Publishing Company.

Loader, J A 1998. The redactional manifestation of Pentateuchal theology. Old Testament Essays 11/3, 487-498.

Lombaard, C J S 1990. Oorredingsveranderlikes in redaksionele kommentaar in koerante: ' $n$ verkenning. Ongepubliseerde MA-verhandeling, Randse Afrikaanse Universiteit.

-, 1996. 'n Nota op die aanwending van "tradisies" in die Suid-Afrikaanse struktuuranalitiese eksegese van die Ou Testament. Skrif en Kerk 17/1, 106-113.

-, 1997. Book review: Sun, T C \& Eades, K L (eds) 1997. Problems in Biblical Theology. Essays in honor of Rolf Knierim. Grand Rapids: William B Eerdmans. Old Testament Essays 11/1, 202-206.

-, 1999. 'n Woord vir ons wêreld. Kontekstuele prediking met behulp van kommentaarjoernalistiek, in Lombaard, C (red.) 1999. “... in die wêreld ..." Vyf bydraes tot kontekstuele prediking, 22-39. Johannesburg: Lewende Woorde (Departement Griekse en Latynse Studies, Randse Afrikaanse Universiteit).

McKim, D K, The "call" in the reformed tradition, in McKim, D K (ed) 1992: Major themes in the reformed tradition, 335-343. Grand Rapids: William B Eerdmans.

Mulholland, J 1994. Handbook of persuasive tactics. A practical language guide. London: Routledge.

Müller, J 1990. Die erediens as fees. Pretoria: NG Kerkboekhandel.

Nel, M 1982. Jeug en evangelie. Pretoria: NG Kerkboekhandel Transvaal.

-, 1994. Gemeentebou. Halfway House: Orion.

Nolan, A 1988. God in South Africa: the challenge of the gospel. Cape Town: David Philip.

Noort, E 1999. Josua en de receptiegeschiedenis als hermeneutisch probleem. Hoofreferaat gelewer, 27 Augustus 1999, tydens die gesamentlike kongres van die OuTestamentiese Werksgemeenskap van Suid Afrika en die Nederlandse Oud Testamentische Werkgeselschap, 25 - 27 Augustus, aan die Fakulteit Teologie, Universiteit van Pretoria. Bydraes van hierdie kongres word eersdaags gepubliseer in die Nederlandse reeks Oud Testamentische Studiën.

Nürnberger, K 1999. The exodus - ethnic identity or revolutionary memory? The trajectory of the exodus paradigm in biblical history and its political relevance today. Missionalia 27/1, 20-61.

Pieterse, H J C 1988. Gemeente en prediking. Pretoria: NG Kerkboekhandel. 
Prinsloo, W S 1996. Eksegese is 'n spel (sonder reëls?). Acta Theologica 1996/2, 2133.

Rall, A 1980. Die boodskap as element in die kommunikasieproses - 'n literatuuroorsig. Pretoria: Raad vir Geesteswetenskaplike Navorsing (Navorsingsbevinding KOMM-N-41.)

Ross, R S \& Ross, M C 1981. Understanding persuasion. Englewood Cliffs: Prentice-Hall, Inc.

Rosouw, H W 1963. Klaarheid en interpretasie. Enkele probleemhistoriese gesigspunte in verband met die leer van die duidelikheid van die Heilige Skrif (VU proefskrif). Amsterdam: Jacob van Campen N.V.

Schweizer, E 1970. The Good News according to Mark. London: John Knox.

Severin, J W \& Tankard, J W Jr 1992. Communication theories: origins, methods, and uses in the mass media (third edition). New York: Longman.

Strijdon, J \& Van Aarde, A G 1990. Markus 16:1-8 in die konteks van 'n rekonstruksie van die Markaanse gemeente. Hervormde Teologiese Studies 46/1 \& 2, 153-189.

Triandis, H C 1971. Attitude and attitude change. New York: John Wiley and Sons.

Von Rad, G 1965/66. About exegesis and preaching, in Von Rad, G (translated by J E Steely) 1977. Biblical interpretation in preaching, 11-18. Nashville: Abingdon.

Vos, C J A 1994. Dansmaats: dogmatiek/etiek en homiletiek. Skrif en Kerk 15/1, 52 64.

Vos, C J A \& Pieterse, H J C 1997. Hoe lieflik is $U$ woning. Pretoria: Raad vir Geesteswetenskaplike Navorsing. (RGN Studies in die Praktiese Teologie.)

Webb, V N 1986. Kommunikasie in die erediens, in Louw, J P, Vosloo, W \& Webb, V N. Die taal van die Bybel en die predikant, 31-63. Pretoria: NG Kerkboekhandel Transvaal.

Williams, F 1984. The new communications. $2^{\text {nd }}$ edition. Belmont: Wadsworth Publishing Company.

Zucker, E 1994. Influence. Portable power for the '90s. Menlo Park, California: Crisp Publications. 